\title{
Examination of Service Quality Models in Research
}

\author{
Sam Stephen Chinnadurai, Selvarani Mariappan
}

\begin{abstract}
In India, the service sector is in a tremendous growth now. It contributes a considerable share in countries GDP. The initiatives of government on financial inclusion and expanding the coverage of the service and development of e-banking creates lot of opportunity for banking sector in terms of innovative financial product, customizes service to the customer. Assessing the service quality and reframing the existing SERQUAl model is necessary to address to the changing trend. In Developed countries, it is quite common that the growth of service sector is more and having good enough competition which makes them to redefine the service quality. This paper aims to the study the existing literature of service quality and prepares a new conceptual model. We used 31 literatures for this study from Elsevier publishers.
\end{abstract}

Keywords: Banking Service, Services, Quality, Service Quality, SERVQUAL.

\section{INTRODUCTION}

$\mathrm{N}$ dimension of the banking chapter. Private Banks are quickly adopting the technology for its banking operations and customer satisfaction .because the heavy competition in banking industry the private banks are forced to do the technology advancements and customer satisfaction are their inevitable work. Consumer loyalty and client maintenance are progressively creating key success elements in banks. Knowledge, specifically has been progressively utilized in service association to upgrade client service quality, reduced cost furthermore, institutionalize center service contributions

The financial situation in India is the post progression and deregulated condition has seen far reaching developments. The huge advances in innovation and the forceful imbuement of information innovation had gotten a viewpoint change in banking activities. Innovation has developed as a key asset for accomplishing higher proficiency.

Another calculated tackle confronting banking establishment today is developing and shifting wants and expectation of customers couple with expanded training levels and developing assets purchasers are became gradually more decreasing furthermore, have turned out to be progressively engaged with their money related choices.

Revised Manuscript Received on December 5, 2019

* Correspondence Author

Sam Stephen Chinnadurai*, Department of Business Administration Kalasalingam Academy of Research and Education, Krishnankoil, India. Email: samstephenc@gmail.com

Selvarani Mariappan, Department of Business Administration Kalasalingam Academy of Research and Education, Krishnankoil, India. Email: selvarani05@gmail.com w a day's Private sector banks are giving new

Thus, they are demanding a worldly range of items and services at more competitive prices through more efficient and convenient channels.

\section{REVIEW OF LITERATURE}

Silvio J.Camilleri et.al (2014) research focus on two important areas (service quality and internet banking) in Maltese retail finance. They used SERVQUAL model to find out the important aspects to customer satisfaction. They found we customers are more concern about the reliability aspect and convenience to access and the author try to find variables to encourage internet banking and financial literacy. They found illiterate people are satisfied with the traditional system

Markus Blut et.al (2015) tries to find out the variables on E-service quality. They used means end chain theory to develop conceptual frame work for examining the construct and test the variables through Meta Analytic technique. They found. Fulfillment, Website design, security/privacy and customer service are important elements in electronic service quality and their overall service quality is governed by industry specific, regulatory environment specific and country specific.

Jaime Torres Fragoso and Ignacio Luna Espinoza (2017) examined the quality of the service provided by BANCOMER \& BANAMEX banks in four cities of Mexico. They used modified version of SERVPERF model. They used all the five variables of the service quality. They found that the customer Expectations of the both banks are high, over all the BANAMEX bank got high grade and another bank got low grade. Comparative analysis indicates this bank need to improve customer service in systems in some branches. Further researcher found both of the banks service is in acceptable level and both need to improve the reliability and responsiveness variables.

Fauziah sh. Ahmad et.al (2014) compares the customer's perception of two different countries namely Malaysia and Turkey about the service quality in grocery retailing. The data is collected from 357 customers of turkey and 249 of Malaysia further the data is analyzed through factor analysis. Results shows that of factor loadings of both the countries RSQS is quite similar the maximum results for turkey is on personal interaction likewise lowest score is problem solving on the other side Malaysian customers having maximum results on physical appearance and lowest is on policy.

Bobby Boon- Hui Chai et.al (2016) examined the influencing factors for bank performance. They found that the performance was triggered by service quality, innovation; bank execution can be improved, further the bank may implement technology in service, and offering innovation in products and services. 


\section{Examination of Service Quality Models in Research}

Goh Mei Ling et.al (2016) understands the elements influenced the client satisfaction towards internet banking. Author identified the five variables for this study i.e., website design, security, service quality content, and privacy on convenience and speed. Author collected 200 samples and the result founded web design, content and convenience and speed are the top factors among the five variables.

Nickolaos G. Tzeremes (2015) Researchanalyzed the banking efficiency of elements of Indian financial industry from 2004to2012. Author used conditional directional distance estimator to analyze effects on industry performance levels. he found that foreign banks perform better compared with nationalized and domestic private sector banks also they found nationalized banks fails to sustain the industry re structuring period they also found the ownership structure also affects technical efficiency level.

Alessandra Dal Colle (2018) this study focuses on liberalization of two aspects i.e. taking deposits and lending. Author used two country economy based Deidda (2006) banking model. Researcher introduces two GATS defined modes for business progression i.e. business nearness and cross fringe mode. Author found threshold effect in terms. This model identifies way reliance among business banking progression and monetary development.

Sana Mohsni and Isaac Otchere (2014) examined the risk taking behavior of before and after LPG. They found that there was a significant difference in private banks after privatization in risk bearing. Privatized banks are more accountable to their share holders. Further they found that a consistent $U$ shaped relationship between private ownership and their risk taking behavior of banks.

Ying Zhu et.al (2018) research focused the effects of macro environmental factors such as history, economy culture and politics on the service quality and service environment on delivery of service. They used expectancy- disconfirmation theory. They found the service provider need to identify the national level factors while providing the cross country level services.

Gyaneshwar Singh Kushwaha and Shiv Ratan Agrawal (2015) research focused on marketing mix elements on Indian customer for making marketing strategy on banking. Collecting data from 351 customers by online questionnaire. They used CFA and SEM analysis and the customer has positive effects on physical evidence, process, place and people.

Muhammad Shoaib Farooq et.al (2018) analysis of quality of service provided by the Malaysian airlines and the customer satisfaction. Author used convenient sampling method to select samples among the population. Data collected from 460 respondents using well designed questionnaire. Researcher used all the five variables of AIRQUAL. Likewise PLS-SEM used for analysis. Results shows that all the five variables are having significant relationship on customer satisfaction further author used IPMA is used to find out the performance of service quality dimensions. Author suggests the company have particular focus on personal services and picture for improving their client liking,

Ajimon George (2018) analyses opinion about internet banking users. Author used TAM model (technology acceptance model) by adding as a external variable (service quality). This study found there is a direct relationship among the TAM variable i.e. PEOU (perceived ease of use) and PU (perceived usefulness). Service quality variables having a indirect relationship on TAM variables.

Ramón Barrera Barrera et.al (2014) examined the real quality of E-services may vary depends upon socio demographic and web graphics variables. Author collected data from 267 customers. Results revealed reality construct is the best and service recovery has the worst performance

Indrajit Sinha and Sujit Mukherjee (2016) this paper focus on investigation and evaluation of off branch E banking in India is not accepted in advanced countries. This study adopted TAM and DOI model data is analyzed through multiple regression models. Researcher found the reason trust on technology, trust on bank, perceived ease of use, perceived usefulness and complexity are the factors to not accept the off branch E- banking.

Alex Fabiano Duarte et.al (2016) analysis of perceived service excellence of monetary services by the members of Parana State Brazil.167 sample is collected. All the variables of SERVQUAL variables included results shows that the employee behavior and self service resources are highly expected.

Shalini Shukla (2014) study focus on the problem of most important challenges undergone by Human resource professionals in Indian banks. The author found lots of difficulties the HR people facing due to tough competition and approximately 70 percent of the public assets that are assets are accounted by banks author suggest reformation HR role in banking sector is certainly needed

Olgun Kitapci et.al (2014) study examined the effects of service quality and identifying the repurchase intention through the word of mouth in health care industry by taking a sample of 369. Author used all the five variables of SERVQUAL and SEM for analyzing the data.They found that the empathy and assurance variable positive role and word of mouth and repurchase intention is having significant relations.

Apostolos N. Giovanis (2014) developed and tested a model to examine the customer loyalty of broad band services in Greece. Author collected data from 573 customers and analyzed using SEM. Results founds real service quality, affecting liking and image of the company trigger a important role in perceived service quality and loyalty

Abdul Rahim Zumrah (2014) research is undergone to find out the relationship between move of knowledge through training and employee service quality. Author found that the training and employee service is having a significant relation of the Malaysian public sector units 
Leena Nitin Fukey et.al (2014) evaluated the various models to hotel industry. Author found, six elements of service delivery mainly used in almost all the hotels. Author identified 15 models and found market, customer focus, motivated staff. And author suggested that most of the models were not satisfied with current scenario so he asked to do some future research too.

Tury Retap et.al (2016) tries to develop the new instrument for measuring is lending relationship quality index (LRQI) to access the relationship Between the quality of lending by banks and SME borrowing customers. This research is done based on the 2000 SME customers on the basis of convenient sampling method. They used CFA for analyze the data they developed one factor lending relationship based on the following variables i.e. trust, amount of information sharing, communication quality of relationship satisfaction with the relationship closeness and long term relationship orientation

Utkarsh Srivastava and Santosh Gopalkrishnan (2015) examined how the big data analytics is used productively in banking business in respect to expenditure prototype of customers, product cross selling based on the profiling to increase hit rate channel usages, sentiment and feedback analysis, customer segmentation and profiling and security and fraud management. They found customer sentiments, transactional analysis are used for bank analysis well.

Sabine Limbourg et.al (2016) examined service quality in logistics they used all the variables of SRVEQUAL. 200 samples are collected from logistic service providers in Da Nang city they found there is a big cape between expectation and perception customers are not satisfied with present service. They suggest LSQ provide more attention to shipping link and freight further they suggest R\&D for customer care programs.

Gi Tae YEO (2015) studied port service quality of Korean container ports. They collected 313 samples from Korean port association. They sued PLS-SEM model to analyze the data they found management, image and social responsibility are playing major role in customer satisfaction

Prodromos Chatzoglou (2014) studied the measure the service quality and customer satisfaction of Hellenic post. They used all the variables of SERVQUAL. They collect 406 samples from customers and 86 from employees of Hellenic post. Result shows that customer are not satisfied with the present service further theyfound assurance alone get the high mean score. On the other hand Hellenic post employees also unaware of customer expectation.

Rachna S. Singh (2014) examined the impact of services in recent economy and success of service sector and analyzing transformation in this sector. This paper mainly focus on characteristics of service business in India and underline its opportunity forecast author found Indian service sector shapes the future business through retail business

Ali Rostami et.al (2016) examined effect of electronic service quality on the improvement of level of correspondence with clients in bank Melli branches of south therain office. They used random sampling method to collect
384 samples from customers they found significant association between the e - service quality and the level of correspondence with clients.

Iberahim, H. et.al (2016) examined ATM service quality of a Malaysian bank and author collected dataform 271 customers of the bank, data analyzed through SPSS. They found only one construct is got good rest of the three construct bank need to improve.

Nesrin Ozatac et.al (2016) studied to find out determinants of in customer satisfaction in service quality of banks. They used SERVQUAL model and collected 207 samples from customers data analyzed through SPSS. They found customer satisfaction depends upon firm relations, and trust between customer and employees and they found word of mouth is good in customer satisfaction

Praveen Goyal and Udayan Chanda (2017) try to identify association of CSR initiatives and perception of service quality. They used Bayesian network analysis and they found customer satisfaction and customer loyalty is increased based on different dimensions of CSR.

\section{CONCLUSION}

Based on the above literature survey author is found the basic model is not avoidable in any circumstance so we define the following model for the research

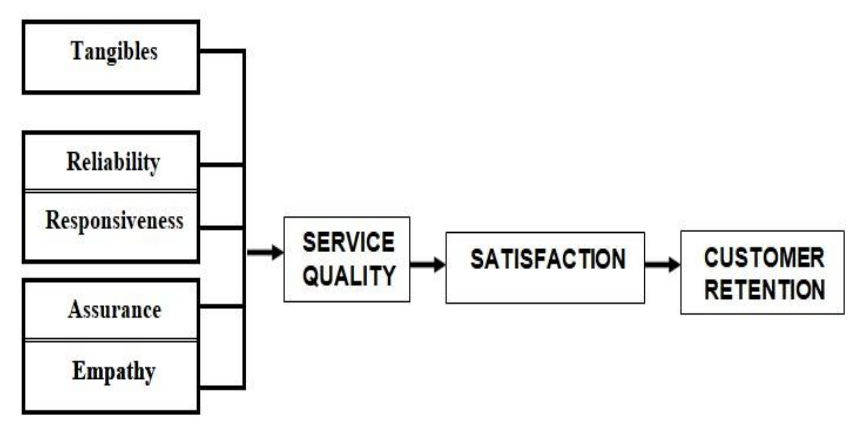

Fig. 1.Service Quality Conceptual Model.

\section{REFERENCES}

1. Silvio J. Camilleri, Justine Cortis and Maria Diandra Fenech "Service quality and internet banking Perceptions of Maltese retail Bank customers" Bank of Valletta Review, No. 48, springer2014

2. Chowdhry, Vikas Mittal ,Markus Blut, Nivriti, "Review E-Service Quality: A Meta-Analytic Review" Christian Brock Journal of Retailing $91(4,2015) 679-700$

3. JaimeTorres Fragoso, Ignacio Luna Espinoza "Assessment of banking service quality perception using the SERVPERF model"Contaduría y Administración 62 (2017) 1294-1316

4. Fauziah Sh. Ahmad, Ali Ihtiyar and Rosmini Omarc "A Comparative Study on Service Quality in the Grocery Retailing: Evidence from Malaysia and Turkey" Procedia - Social and Behavioral Sciences 109 (2014) 763 - 767

5. Bobby Boon-Hui Chai, Pek See Tan, Thian Shong Goh "Banking Services that Influence the Bank Performance" Procedia- Social and Behavioral Sciences 224 ( 2016 ) $401-407$ 


\section{Examination of Service Quality Models in Research}

6. Goh Mei Ling, Yeo Sook Fern, Lim Kah Boon, Tan Seng Huat "Understanding Customer Satisfaction of Internet Banking: A Case Study In Malacca "Procedia Economics and Finance 37 ( 2016) 80 - 85

7. Nickolaos G. Tzeremes"European Journal of Operational Research" European Journal of Operational Research 240 (2015) 807-818

8. Alessandra Dal Colle "The mechanics of commercial banking liberalization and growth" Journal of Banking and Finance 86 (2018) 194-203

9. Sana Mohsni, Isaac Otchere "Risk taking behavior of privatized banks", Journal of Corporate Finance 29 (2014) 122-142

10. Ying Zhu, Susan Freeman, S. TamerCavusgil "Service quality delivery in a cross-national "https://doi.org/10.1016/j.ibusrev.2018.03.002

11. Gyaneshwar Singh Kushwaha, Shiv Ratan Agrawal "An Indian customer surrounding 7P's of service marketing" Journal of Retailing and Consumer Services 22 (2015) 85-95

12. Muhammad Shoaib Farooq, Maimoona Salam, Alain Fayolle, Norizan Jaafar , Kartinah Ayupp "Impact of service quality on customer satisfaction in Malaysia airlines: A PLS-SEM approach" Journal of Air Transport Management 67 (2018) 169-180

13. Ajimon George "Perceptions of Internet banking users - a structural equation modeling (SEM) approach" IIMB Management Review (2018) $000,1-12$

14. Evaluation of the e-service quality in service encounters with incidents: Differences according to the socio-demographic profile of the online consumer Ramón Barrera Barrera, Antonio Navarro García, Manue Rey Moreno Revista Europea de Dirección y Economía de la Empresa 23 (2014) 184-193

15. Indrajit Sinha, Sujit Mukherjee "Acceptance of technology, related factors in use of off branch e-banking: an Indian case study" Journal of High Technology Management Research 27 (2016) 88- 100

16. Alex Fabiano Duarte, Vilmar Rodrigues Moreira, Alex Antônio Ferraresi, Alcimar Gerhard "Evaluating credit union members' perception of service quality through service innovation" RAI Revista de Administração e Inovação 13 (2016) 242-250

17. Shalini Shukla "Emerging issues and challenges for HRM in public sectors banks of India", Procedia - Social and Behavioral Sciences 133 (2014) $358-363$

18. Olgun Kitapci, Ceylan Akdogan , İbrahim Taylan Dortyol "The Impact of Service Quality Dimensions on Patient Satisfaction, Repurchase Intentions and Word-of-Mouth Communication in the Public Healthcare Industry" Procedia - Social and Behavioral Sciences 148 ( 2014 ) 161 169

19. Apostolos N. Giovanis , Dimitris Zondiros , Petros Tomaras "The antecedents of customer loyalty for broadband services: The role of service quality, emotional satisfaction and corporate image" Procedia Social and Behavioral Sciences 148 ( 2014 ) 236 - 244

20. Abdul Rahim Zumrah "Service quality in Malaysian public sector: The role of transfer of training" Procedia - Social and Behavioral Sciences 144 (2014) $111-117$

21. Leena Nitin Fukey, Surya Sarah Issac, Kandappan Balasubramanian Jaykumar V "Service Delivery Quality Improvement Models: A Review" Procedia - Social and Behavioral Sciences 144 ( 2014 ) 343 359

22. Tury Retap , Firdaus Abdullah, Jamil Hamali 'Banks' Lending Relationship Quality Index (LRQI) for the Small and Medium-sized Enterprises: A Review" Procedia - Social and Behavioral Sciences 224 ( 2016 ) $408-415$

23. Utkarsh Srivastava , Santosh Gopalkrishnan "Impact of Big Data Analytics on Banking Sector: Learning for Indian Banks" Procedia Computer Science 50 ( 2015 ) 643 - 652

24. Limbourg, Ho Thi Quynh Giang , Mario Cools "logistics Service Quality: The Case of Da Nang City Sabine” Procedia Engineering 142 ( 2016 ) $124-130$

25. Ports Gi Tae YEO, Vinh V. THAI , Sae Yeon "An Analysis of Port Service Quality and Customer Satisfaction: The Case of Korean Container ROH" The Asian Journal of Shipping and Logistics 31(4) (2015) 437-447

26. Prodromos Chatzoglou, Dimitrios Chatzoudes, Eftichia Vraimaki, Eleni Leivaditou "Measuring citizen satisfaction using the SERVQUAL approach: the case of the "Hellenic post"" Procedia Economics and Finance 9 ( 2014 ) 349 - 360

27. Rachna S. Singh "India's Service Sector - Shaping Future of Indian Retail Industry" Procedia Economics and Finance 11 (2014) 314 - 322

28. Ali Rostami , Amir Hossein Amir Khani ,Gholamali Soltani "The Impact of E-service Quality on the Improvement of the Level of Communication with Customers of Bank Melli Branches in South
Tehran Affairs Office” Procedia Economics and Finance 36 ( 2016 ) $448-455$

29. Iberahim, H, Mohd Taufik, N.K. , Mohd Adzmir, A.S. \& Saharuddin, H. "Customer Satisfaction on Reliability and Responsiveness of Self Service Technology for Retail Banking Services". Procedia Economics and Finance 37 (2016) 13 - 20

30. Nesrin Ozatac,Tulen Saner , Zeynep Suzmen Sen "Customer Satisfaction in the Banking Sector: The Case of North Cyprus"Procedia Economics and Finance 39 ( 2016 ) 870 - 878

31. Praveen Goyal a,1 , Udayan Chanda "A Bayesian Network Model on the association between CSR, perceived service quality and customer loyalty in Indian Banking Industry"sustainable production and consumption 10 (2017) 50-65

\section{AUTHORS PROFILE}

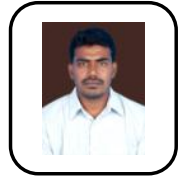

Sam Stephen Chinnadurai is currently doing his full time research in Kalasalingam Business School, Kalasalingam Academy of Research and Education (Kalasalingam deemed to be University).he has nine years of industrial experience in various companies and one year of teaching experience in KARE

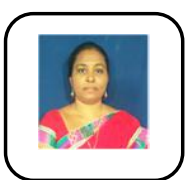

Selvarani Mariappan is currently working in Kalasalingam Business School, Kalasalingam Academy of Research and Education (Kalasalingam deemed to be University). She completed MBA from Mepco Schlenk Engineering College, India and ICWA Inter. She obtained her Doctorate from Kalasalingam University and is a researcher and teacher in the area of finance for more than 16 years. She expertise in stock market behavioral research and underwent FDP program on Econometrics in IIM, Kozhikode and published more research papers in a SCOPUS indexed journal and reviewer of finance journals. She contributed her research work as chapter in books. She writes extensively and presented papers in International and National Conference organised by IIT, IIM's and publishes scholarly works and case study. She got trained by Infosys on Global Business Foundation Skill and NIT on Analytics. She conducted FDP, Workshop and gave guest lecture to Students, employees and research Scholars. She acted as a BOS member for SFR College, Sivakasi. She got awards for her competency in teaching for two times and faculty advisory ship from IQAC, KARE. 